\title{
CONSUMER SATISFACTION WITH COMMUNITY MENTAL HEALTH CARE IN DURBAN
}

\author{
Renée Almeida \\ MN \\ Senior Tutor, School of Nursing, University of Natal
}

\section{Oluyinka Adejumo}

D Litt et Phil

Associate Professor, School of Nursing, University of Natal

Corresponding author: adejumoo@nu.ac.za

Keywords: consumer satisfaction; psychiatric community health clinic; mental health service delivery; Durban, South Africa

\begin{abstract}
This study presents a consumer evaluation of the delivery and aspects of services provided at three communityrun mental health centres with the aim of using this information to improve the services in future for quality assurance. One hundred and eleven clients attending the psychiatric community health clinics responded to a self-report questionnaire that elicited information on their satisfaction with several aspects of their clinical care in community mental health services. Items on the questionnaire included clients' level of overall satisfaction and degree of acceptability of the services to the clients, the effectiveness of health care service delivery, clients' views of the quality and outcome of therapy, the clinic's effectiveness, future behaviour in similar situations, and recommendations of the clinic to others. Analysis of findings indicated that participants were generally satisfied with the mental health service provided, with suggestions for some areas of care needing attention. Recommendations were made for improving certain aspects of follow up care and for additional studies in other settings to include appropriate proportions of all racial groups in South Africa.
\end{abstract}

\section{OPSOMMING}

Hierdie studie handel oor ' $n$ verbruikersevaluering van die lewering van dienste en aspekte daarvan wat aan die drie gemeenskapsonderhoudende geestesgesondheidsentra gelewer is met die doel om hierdie inligting te gebruik om die dienste in die toekoms vir kwaliteitsversekering te verbeter. Eenhonderd-en-elf kliënte wat die klinieke vir psigiatriese gemeenskapsgesondheid besoek het, het op 'n selfverslag-vraelys gereageer wat hulle tevredenheid met verskillende aspekte van hulle kliniese sorg in die gemeenskapsgeestesgesondheidsdienste aan die lig gebring het. Items in die vraelys het kliënte se vlak van algehele tevredenheid en graad van aanvaarbaarheid van die dienste aan die kliënte, die effektiwiteit van gesondheidsorglewering, kliënte se menings oor die kwaliteit en uitkomste van terapie, die kliniek se effektiwiteit, toekomstige gedrag in soortgelyke situasies, en aanbevelings van die kliniek aan ander inges/uit. ' $n$ Analise van die bevindinge het aangedui dat deelnemers oor die algemeen tevrede was met die geestesgesondheidsdienste wat gelewer is, met voorstelle vir sekere aspekte van sorg wat aandag nodig het. Aanbevelings is gemaak om sekere aspekte van opvolgsorg te verbeter en vir verdere studies in ander omstandighede om toepaslike verhoudings van alle rassegroepe in Suid-Afrika in te sluit. 


\section{INTRODUCTION}

In this era of fiscal restraint and decreased government support for human services, it is essential that community mental health programmes demonstrate their usefulness to the public through careful evaluation of their service. One important component of the evaluation of such public funded delivery systems is an assessment of the satisfaction of the citizens who receive treatment through their appraisals of both the clinical and the administrative aspects of their care. Research in this area can be used to make services more acceptable to users and encourage better use of services. In this respect the service user offers a unique perspective on the treatment process, particularly the patterns of communication during consultations (Fitzpatrick, 1991:889).

Frisk, Brown, Cannizzaro and Naftal (in Kolb \& Race, 2000:2) argue that total satisfaction with service is the primary determinant of a consumer's intent to reuse or recommend and have identified patient surveys as an essential component of a comprehensive and effective patient satisfaction management system. Satisfaction is related to improvements in health status (Wykes \& Carrol, 1993:339). In a study conducted by Pekarik (1992:91), approximately equal proportions of adults cited perceived improvement, environmental obstacles and dissatisfaction as the most common reason for dropping out.

Although evaluations of patient satisfaction are in widespread use, research on the topic has yielded only sparse and frequently conflicting information (Lebow, 1982:255). One perspective for obtaining evaluation information is to solicit reactions from consumers. Even when clients participated in the evaluative process, they are traditionally placed in the role of the ones being evaluated. There has however been a significant shift toward broadening the scope of client participation in the evaluation of human service programmes. Damkot, Pandiani and Gordon (1983:266) believe that systemic, regular and iterative samples of client and past-client opinions must become one component of community mental health centres' self review, programme planning and development.
Although consumer satisfaction has been studied extensively internationally, consumers' views about the psychiatric services in this country have not been systematically explored and are a neglected component of health service delivery. Consumer opinion is therefore particularly needed in ambulatory care settings where providers have less control over adherence to treatments prescribed than they might have in a hospital setting. Certainly a patient is the best judge of a provider's concern, sincerity, compassion and respect in the course of receiving treatment and care.

Given that the fundamental reason is for the health worker to serve the needs and wishes of the patient and work towards the good of the patient, an understanding of patients' concerns and interest is central (Carr-Hill, 1992:236). Just as acceptability greatly determines use and pursuit of mental health services, it also has strong influence on treatment (Kalman, 1983:48). Satisfaction with care received, therefore, has an important influence on whether a person seeks medical advice, complies with treatment and its eventual success, as well as whether a person maintains a continuing relationship with a practitioner.

\section{PURPOSE OF THE STUDY}

The purpose of this study is to describe the satisfaction levels of consumers with mental health service delivery in Durban, with a view to using this information to improve the services in future for quality assurance.

\section{OBJECTIVES OF THE STUDY}

The study was designed to achieve the following objectives:

1. to identify if the services received meet the expectations of care that consumers have of mental health service delivery;

2. to assess the level of satisfaction that the consumers have with the services; and

3. to assess the acceptability of the services consumers receive in the selected clinics.

\section{DEFINITIONS OF TERMS}

The following terms are used to convey the following meanings in this study: 
Satisfaction - is the extent to which treatment gratifies the wants, wishes and desires of clients for services.

Acceptability - is the possibility of the patients returning for the same service if they were to seek help again.

Quality - is the degree to which the mental health services increase the likelihood of desired health outcomes in the clients.

\section{METHODS}

\section{Research design and setting}

A descriptive survey approach was used for this study. Three clinics attending to similar mental health conditions and serving three different race groups were selected for the study in order to establish a distribution of strategic positioning of services geographically. The first setting for this study is a mental health care clinic situated in central Durban. Although this clinic serves a mixed population, the consumers are predominantly White. The second setting for the study is a mental health care clinic situated in Durban North, where the consumers are predominantly of Indian origin. The third clinic is situated in Durban South, where the consumers are predominantly of the Coloured population.

\section{Study population}

The population of this study are all eligible consumers of mental health service delivery attending the three clinics during the study period who agreed to participate in the study. The average daily clinic attendance in these settings is as follows:

$\begin{array}{ll}\text { Clinic 1 } & 215 \\ \text { Clinic 2 } & 130 \\ \text { Clinic 3 } & 211 \\ \text { Total per day } & 556\end{array}$

\section{Sample}

A $20 \%$ non-probability purposive sample of average daily attendance at each setting was selected for the study. Criteria for inclusion in the study were that each participant was 18 years and older, currently in treatment and attending clinics; and were symptomatically stable to be able to provide valid information. Clients who were identified to fulfil these criteria by the attending nurses were approached in the waiting room or referred by the nursing sisters to a private room until the determined number for each clinic was achieved. In total 111 clients were selected to participate in the study.

\section{Instruments}

A client satisfaction questionnaire (CSQ-8), which is an eight-item questionnaire used to measure client satisfaction developed by Larsen, Attkisson, Hargreaves and Nguyen (1979:204), was adapted for use in this study. It consists of eight Likert-type items with four response choices, where one indicates the lowest rating of quality or degree of satisfaction and four indicates the highest. The first part of the instrument contained demographic characteristics of the respondents to determine age, education, gender, race group and how long the respondent had been visiting the clinic. These variables were selected in an attempt to determine the predictive capacity of the patient demographic variables in forecasting outcome.

The questionnaire was translated into Zulu to cater for the non-English speaking clients. The respondents had an option to choose either English or Zulu as a language medium.

\section{Procedure}

Data was collected over a six-day period during which all clients who met the inclusion criteria were asked to complete the questionnaire in a private or waiting room. The respondents were asked to rate the quality of the service received in the clinic on a 4-point scale ranging from "excellent" to "poor". Patients were also asked if their needs were met on a 4-point scale ranging from "almost all of my needs have been met" to "none of my needs have been met". The question that asked whether the services helped to deal more effectively with clients' problems on a 4-point scale ranged from "yes, they helped a great deal" to "no, they seemed to make things worse". The last item asked if they would come back to the clinic, if they were to seek help on a 4-point scale ranging from "no, definitely" to "yes, definitely". 
Face-to-face interviews were conducted for the nonliterate respondents using the tool to collect the responses, while the literate ones completed the questionnaires themselves. A portion of the tool also requested for the clients to give free comments about their feelings and possible suggestions regarding the services received in the mental health clinics.

Permission was obtained from the Director of Community Psychiatric Services and Clinics and the managers of the three clinics. Informed consent was sought from each participant after explaining to them the purpose of the study and guaranteeing the confidentiality and the anonymity of the interview.

\section{Findings}

The Statistical Package for Social Sciences (SPSS) was used for the descriptive and inferential statistical analysis of the data collected in this study. A total of 111 responses were analysed and the findings are set out in Table 1.

Table 1 shows the characteristics of the respondents in the study. The ages of participants ranged from 18 to 79 years. The mean age of the respondents in the study was 41.42 (Clinic $1=43.90$; Clinic $2=38.1$; and Clinic $3=42.26$ ). Males were dominant in all the clinics (males $=62.2 \%$, and females $=37.8 \%$ ). The sample comprised of Blacks 5 (4.5\%), Indians 30 (27.0\%), Coloureds 40 (36\%), and Whites 36 (32.4\%). The majority of the respondents had education beyond primary school level. Only $14.4 \%$ of the respondents were employed at the time of the study.

Table 1: Respondents' characteristics

\begin{tabular}{|c|c|c|c|c|}
\hline Description & Clinic 1 & Clinic 2 & Clinic 3 & Total \\
\hline Total no. of respondents & 43 & 26 & 42 & $111(100 \%)$ \\
\hline \multicolumn{5}{|l|}{ Age distribution } \\
\hline Range & $25-79$ & $18-57$ & $22-70$ & \\
\hline Mean & 43.90 & 38.1 & 42.26 & \\
\hline Standard deviation & 12.86 & 11.24 & 10.64 & \\
\hline Gender distribution & $\mathbf{N}(\%)$ & $N(\%)$ & $N(\%)$ & $N(\%)$ \\
\hline Female & $19(44.2) \%$ & $7(26.9) \%$ & $16(38.1) \%$ & $42(37.8 \%)$ \\
\hline Male & $24(55.8) \%$ & $19(73.1) \%$ & $26(61.9) \%$ & $69(62.2 \%)$ \\
\hline \multicolumn{5}{|l|}{ Race } \\
\hline Black & $4(9.3)$ & $1(3.8 \%)$ & - & $5(4.5 \%)$ \\
\hline Indian & $4(9.3)$ & $24(92.3 \%)$ & $2(4.8 \%)$ & $30(27.0 \%)$ \\
\hline Coloured & $3(7.0)$ & $1(3.8 \%)$ & $36(85.7 \%)$ & $40(36 \%)$ \\
\hline White & $32(74.4)$ & - & $4(9.5 \%)$ & 36 (32.4\%) \\
\hline \multicolumn{5}{|l|}{ Educational level } \\
\hline Primary school & $2(4.7 \%)$ & $8(30.8 \%)$ & $9(21.4 \%)$ & $19(17.1 \%)$ \\
\hline Secondary school & $38(88.4 \%)$ & $16(61.5)$ & $30(71.4 \%)$ & $84(75.7 \%)$ \\
\hline Diploma & $2(4.7 \%)$ & $1(3.8 \%)$ & $2(4.8 \%)$ & $5(4.5 \%)$ \\
\hline Post-graduate & $1(2.3 \%)$ & $1(3.8 \%)$ & $1(2.4 \%)$ & $3(2.7 \%)$ \\
\hline \multicolumn{5}{|l|}{ Employment status } \\
\hline Employed & $9(20.9 \%)$ & $4(15.4 \%)$ & $3(7.1 \%)$ & $16(14.4 \%)$ \\
\hline Unemployed & $34(79.1 \%)$ & $22(84.6 \%)$ & 39 (92.9\%) & $95(85.6 \%)$ \\
\hline \multicolumn{5}{|l|}{ Length of visit in years } \\
\hline Mean & 6.27 & 9.30 & 8.30 & \\
\hline Minimum & 0.50 & 2.0 & 1.0 & \\
\hline Maximum & 28.0 & 29.0 & 31.0 & \\
\hline
\end{tabular}


Table 2: Clients' satisfaction with care received

\begin{tabular}{|c|c|c|c|c|c|}
\hline Item & Response & Clinic 1 & Clinic 2 & Clinic 3 & Total \\
\hline \multirow{4}{*}{$\begin{array}{l}\text { Does the service } \\
\text { received meet your } \\
\text { expectations? }\end{array}$} & No, definitely not & - & - & $2(4.8 \%)$ & $2(1.8 \%)$ \\
\hline & No, not really & $3(7.0 \%)$ & $1(3.8 \%)$ & $2(4.8 \%)$ & $6(5.4 \%)$ \\
\hline & Yes, generally & $12(27.9 \%)$ & $11(42.3 \%)$ & $18(42.9 \%)$ & $41(36.9 \%)$ \\
\hline & Yes, definitely & $28(65.1 \%)$ & $14(53.8 \%)$ & $20(47.6 \%)$ & 62 (55.9\%) \\
\hline \multirow{4}{*}{$\begin{array}{l}\text { Satisfaction with the } \\
\text { amount of help } \\
\text { received from the } \\
\text { health care provided } \\
\text { in this clinic }\end{array}$} & Not satisfied & $7(16.3 \%)$ & $7(26.9 \%)$ & $11(26.2 \%)$ & $25(22.5 \%)$ \\
\hline & Mildly dissatisfied & $1(2.3 \%)$ & $1(3.8 \%)$ & $3(7.1 \%)$ & $5(4.5 \%)$ \\
\hline & Mostly satisfied & 15 (34.9\%) & $3(11.5 \%)$ & $11(26.2 \%)$ & $29(26.1 \%)$ \\
\hline & Very satisfied & $20(46.5 \%)$ & $15(57.7 \%)$ & $17(40.5 \%)$ & $52(46.8 \%)$ \\
\hline \multirow{4}{*}{$\begin{array}{l}\text { To what extent has } \\
\text { the services received } \\
\text { in the clinic met your } \\
\text { needs? }\end{array}$} & $\begin{array}{l}\text { None of my needs } \\
\text { met }\end{array}$ & & & & \\
\hline & A few needs met & $4(9.3 \%)$ & $5(19.2 \%)$ & $8(19.0 \%)$ & $17(15.3 \%)$ \\
\hline & Most needs met & $20(46.5 \%)$ & $9(34.6 \%)$ & $21(50.0 \%)$ & $50(45.0 \%)$ \\
\hline & $\begin{array}{l}\text { Almost all needs } \\
\text { met }\end{array}$ & $19(44.2 \%)$ & $12(46.2 \%)$ & $13(31.0 \%)$ & $44(39.6 \%)$ \\
\hline \multirow{4}{*}{$\begin{array}{l}\text { Rate your general } \\
\text { level of satisfaction } \\
\text { with the care received } \\
\text { in this clinic. }\end{array}$} & Quite dissatisfied & - & - & $1(2.4 \%)$ & $1(.9 \%)$ \\
\hline & Mildly dissatisfied & $1(2.3 \%)$ & $2(7.7 \%)$ & $5(11.9 \%)$ & $8(7.2 \%)$ \\
\hline & Mostly satisfied & $14(32.6 \%)$ & $7(26.9 \%)$ & $15(35.7 \%)$ & $36(32.4 \%)$ \\
\hline & Very satisfied & $28(65.1 \%)$ & $17(65.4)$ & $21(50 \%)$ & 66 (59.5\%) \\
\hline \multirow{4}{*}{$\begin{array}{l}\text { Would you come } \\
\text { back to this clinic if } \\
\text { you were to seek help } \\
\text { for the same reason } \\
\text { again? }\end{array}$} & No, definitely not & - & - & $1(2.4 \%)$ & $1(.9 \%)$ \\
\hline & $\begin{array}{l}\text { No, I don't think } \\
\text { so }\end{array}$ & $1(2.3 \%)$ & $1(3.8 \%)$ & $2(4.8 \%)$ & $4(3.6 \%)$ \\
\hline & Yes, I think so & $13(30.2 \%)$ & $4(15.4 \%)$ & $13(31.0 \%)$ & $30(27.0 \%)$ \\
\hline & Yes, definitely & $29(67.4 \%)$ & $21(80.8 \%)$ & $26(61.9 \%)$ & $76(68.5 \%)$ \\
\hline \multirow{4}{*}{$\begin{array}{l}\text { Rate the quality of } \\
\text { mental health service } \\
\text { received by you in the } \\
\text { clinic. }\end{array}$} & Poor & $2(4.7 \%)$ & - & $1(2.4 \%)$ & $3(2.7 \%)$ \\
\hline & Fair & $3(7.0 \%)$ & $1(3.8 \%)$ & $8(19.0 \%)$ & $12(10.8 \%)$ \\
\hline & Good & $11(25.6 \%)$ & $7(26.9 \%)$ & $18(42.9 \%)$ & $36(32.4 \%)$ \\
\hline & Excellent & 27 (62.8\%) & $18(69.2 \%)$ & 5 (35.7\%) & $60(54.1 \%)$ \\
\hline \multirow{4}{*}{$\begin{array}{l}\text { If a friend were in } \\
\text { need of similar help, } \\
\text { would you } \\
\text { recommend our } \\
\text { services to him or } \\
\text { her? }\end{array}$} & No, definitely not & - & - & - & - \\
\hline & $\begin{array}{l}\text { No, I don't think } \\
\text { so }\end{array}$ & - & - & $1(2.4 \%)$ & $1(.9 \%)$ \\
\hline & Yes, I think so & $15(34.9 \%)$ & $6(23.1 \%)$ & $18(42.9 \%)$ & $39(35.1 \%)$ \\
\hline & Yes, definitely & $28(65.1 \%)$ & $0(76.9 \%)$ & $23(54.8 \%)$ & $71(64.0 \%)$ \\
\hline \multirow{4}{*}{$\begin{array}{l}\text { On service } \\
\text { effectiveness: How } \\
\text { did the services help } \\
\text { to deal with your } \\
\text { problems? }\end{array}$} & $\begin{array}{l}\text { No, they made } \\
\text { things worse }\end{array}$ & - & - & $1(2.4 \%)$ & $1(.9 \%)$ \\
\hline & $\begin{array}{l}\text { No, they really } \\
\text { didn't help }\end{array}$ & - & $1(3.8 \%)$ & $2(4.8 \%)$ & $3(2.7 \%)$ \\
\hline & $\begin{array}{l}\text { Yes, they helped } \\
\text { somewhat }\end{array}$ & $10(23.3 \%)$ & $5(19.2 \%)$ & $13(31.0)$ & $28(25.2 \%)$ \\
\hline & $\begin{array}{l}\text { Yes, they helped } \\
\text { a great deal }\end{array}$ & $33(76.7 \%)$ & 20 (76.9\%) & $26(61.9 \%)$ & 79 (71.2\%) \\
\hline
\end{tabular}


Table 2 presents the summary of the clients' satisfaction or lack of satisfaction with the care received. Most of the respondents $(92.8 \%)$ appeared to have their expectations of the services met, but $7.2 \%$ of the total number of respondents did not seem to feel the same way. Thirty $(27.0 \%)$ appeared to be either not satisfied or mildly dissatisfied with the amount of help received from the services, while 81 (72.9\%) appeared to be either mostly or very satisfied with the services received. The needs of $84.6 \%$ of the respondents however appeared to have been met, while $15.3 \%$ could only claim a few of their needs met.

Asked to respond about their general satisfaction with the services received, most respondents (91.9\%), were generally satisfied with the service they had received. Only $8.1 \%$ of the respondents appeared to be either quite dissatisfied or mildly dissatisfied. The services would also seem to be generally acceptable to the respondents as only $4.5 \%$ of the respondents reported that they would not come back to the same clinic if they were to seek help for the same problem again.

When asked to rate the quality of mental health service received in the clinic, $96(86.5 \%)$ rated this aspect of the service as either good or excellent, while 15 $(13.5 \%)$ of the respondents considered the quality as either poor or fair. Most of the respondents (99.1\%) were likely to recommend the services to a friend if such friend were in need of similar help. The respondents (96.4\%), appeared to be positive about the services in terms of how these had helped to deal with their problems, but $4(3.6 \%)$ of the respondents did not seem to feel this way.

Further statistical chi-square analysis did not yield any significant difference at $p=0.05$, when the clinics were compared item by item on the response to the CSQ. The chi-square analysis also failed to yield any significant difference among the race groups or other demographic characteristics of gender and even level of education.

Open comments from the respondents were mainly categorised into favourable and unfavourable responses in terms of satisfaction with the activities in the clinics attended. Samples of favourable comments are typified by the following: "The staffs are very dedicated and sympathetic towards us, although there is a whole lot of pressure from some of the patients". "The clinic has given me a chance to lead a normal life and I have a good relationship with various staff." "The Doctor is very patient caring understanding, helpful and accommodating."

Other comments enlisted that were not on the positive side were as follows: "The waiting period is too long to see the doctor and collect medication. More doctors are required." "The doctor is very abrupt and rude. He does not listen to me and makes decision without talking to me". "Sometimes the sisters talk to you disrespectfully and they behave as if you don't know what you are talking about. The patient does not necessarily have to be wrong always." "The nurses must give more information to me."

\section{DISCUSSION}

The findings in the present study are consistent with those of Balch, Ireland, McWilliams and Lewis (1977:246), Larsen et al. (1979:202), Lebow (1982:251) and Vincente, Vielma, Jenner, Mezzina and Lliapas (1993:124), that levels of satisfaction, attitudes and opinions were largely unrelated to personal variables. It appeared that the people reached for this study were quite satisfied with the clinic services. The high rate of client satisfaction is also consistent with other studies (Denner \& Halprin, 1974:18; Balch et al. 1977:245; Larsen et al. 1979:198; Stallard, 1996) that have found that clients usually report being quite satisfied with services.

Assessing client satisfaction is important, not only for treatment considerations, but also to ensure that cost saving measures does not affect client satisfaction with treatment. In general, patients were satisfied and they believed that the care was often effective. The value of the study lies in the awareness staff may have gained of patients' assessment of service provided, and the fact that there are exceptions to all the rules with certain clients, though minimal in this study, reporting lack of satisfaction in certain aspects of the services. Further studies will have to focus on specific aspects of care or activities in the clinic that might not be satisfactory to the clients. In this study, particular mention was made of the waiting period, and the attitude of some attending staff. These are aspects of care that 
might need attention, re-orientation, staff induction, clients' education, and other interventions that might serve to improve the quality of care, the acceptance of the service and generally the satisfaction that the clients receive from such services.

\section{Limitations of the study}

The respondents in this study were purposively selected based on their assessed mental health status. This in itself may have introduced some bias into the selection of patients that might be perceived as "not difficult" by the staff. Perhaps the outcome of the study might have been different if the sample was selected more randomly, though the mental health status of the clients who might not able to respond rationally at the time of the study would still have compromised the outcome of the study.

\section{CONCLUSION}

The key issue in future research will be the enhancement of our capacity to detect dissatisfied consumers, whether in stable or non-stable clients. For such evaluations to become more useful for planning programme policies and services, there is a need for a multidimensional examination of patient satisfaction, with specific exploration of the patients' views of the clinical and administrative aspects of their care. Although, this study has its limitations, it can provide meaningful data to administrators concerning the ongoing delivery of care and help them plan patterns of practice for the future. Satisfaction with care is only one part of patient outcome. One would hope that increased satisfaction would be associated with other types of outcomes measured by reduction in symptoms and hospitalisation rates. Results from studies such as this can be used by individual programmes to market their services to the community or to improve client treatment through a more detailed analysis intended to measure specific programme strengths and weaknesses. Replication of the current study with different populations and different tools is needed to enhance the generalisability of the results, especially with Blacks that are under-represented in this study. Further study of satisfaction in sites other than community mental health centres is needed, especially in the private health sector.

\section{REFERENCES}

BALCH, P; IRELAND, JF; MCWILLIAMS, SA \& LEWIS, SB 1977: Client evaluation of community mental health services: Relation to demographic and treatment variables. American Journal of Community Psychology, 5(2):243-247.

CARR-HILL, R 1992: The measurement of patient satisfaction. Journal of Public Health Medicine, 14(3): 236-249.

DAMKOT, DK; PANDIANI JA \& GORDON LR 1983: Development, implementation and findings of a continuing client satisfaction survey. Community Mental Health Journal, 19:265-278.

DENNER, B \& HALPRIN, F 1974: Measuring consumer satisfaction in a community outpost. American Journal of community Psychology, 2(1):13-22.

FITZPATRICK, R 1991: Surveys of patient satisfaction: 1 - Important general consideration. British Medical Journal, 302:887889.

KALMAN, TP 1983: An overview of patient satisfaction with psychiatric treatment. Hospital and Community Psychiatry, 34(1):4854.

KOLB, SJ \& RACE, KEH 2000: Psychometric evaluation of an inpatient psychiatric care consumer satisfaction survey. Journal of Behavioural Health Service and Research, 27(1):75-87. LARSEN, DL; ATTKISSON C; HARGREAVES W \& NGUYEN T 1979: Assessment of client/patient satisfaction: development of a general scale. Evaluation and Programme Planning, 2:197207.

LEBOW, J 1982: Consumer satisfaction with mental health treatment. Psychological Bulletin, 91(2):244-259.

PEKARIK, G 1992: Relationship of clients' reasons for dropping out of treatment to outcome and satisfaction. Journal of Clinical Psychology, 48(1):91-98.

STALLARD, P 1996: The role and use of consumer satisfaction surveys in mental health services. Journal of Mental Health, 5(4): 333-348.

VINCENTE, B; VIELMA, M; JENNER, FA; MEZZINA, R \& LLIAPAS, I 1993: Users' satisfaction with mental health services. International Journal of Social Psychiatry, 39(2):121-130.

WYKES, T \& CARROL, S 1993: Patient satisfaction with intensive care psychiatric services: Can it be assessed? Journal of Mental Health, 2:330-347. 